\title{
Brood pupation temperature affects the susceptibility of honeybees (Apis mellifera) to infestation by tracheal mites (Acarapis woodi) $^{1}$
}

\author{
John B. MCMuLLAN*, Mark J.F. BROWN \\ Department of Zoology, Trinity College Dublin, Dublin 2, Ireland
}

Received 12 March 2004 - Revised 1 July 2004 - Accepted 26 July 2004

Published online 16 March 2005

\begin{abstract}
An assessment was made of tracheal mite susceptibility in honeybees pupated at a low temperature. Using a laboratory bioassay, an experiment was conducted to compare the performance of newly-emerged (callow) bees raised at $30^{\circ} \mathrm{C}$ with those raised at the more normal brood temperature of $34^{\circ} \mathrm{C}$. The reduced temperature caused a delay of over 5 days in the emergence of the bees from the brood cells. The callow bees raised at $30^{\circ} \mathrm{C}$ had over twice the mite prevalence level. The fecundity of the mites in the tracheae was similar for both temperature conditions. Increased susceptibility to tracheal mites resulting from reduced brood temperature may help to explain the mortality, in the temperature-stressed late winter/early spring period, of colonies with a moderate mite infestation in autumn. Further work is required to identify the mechanism responsible for this increased susceptibility.
\end{abstract}

Apis mellifera / Acarapis woodi / tracheal mite / brood temperature / susceptibility to infestation

\section{INTRODUCTION}

The tracheal mite, Acarapis woodi (Rennie) has been associated with an epidemic in honeybees (Apis mellifera L.) that first appeared one hundred years ago. The 1904 mortality of honeybees in the South of England (that later spread to the rest of Britain, Ireland and mainland Europe) became known as the 'Isle of Wight disease' (Adam, 1968). The tracheal mite was identified for the first time in 1919 during a search to discover the cause of the 'Isle of Wight disease' (Rennie, 1921). In Europe tracheal mite infestation was initially associated with high levels of bee mortality, which eventually settled down at much lower levels. There is no consensus on the reason for the colony deaths. Bailey and Ball (1991) believe that many disorders, most notably viral paralysis, were wrongly attributed to the tracheal mite. However, the tracheal mite was first recorded in North America in 1984 and subsequently the honeybee colonies were devastated for more than a decade with little evidence of other pathogens having a prominent role (Collison, 2001).

In the aftermath of this mortality, research was mainly undertaken to control tracheal mite infestation through the use of chemicals as well as identifying resistant strains of honeybee (Danka, 1991). Acarapis woodi mites reproduce in the tracheae of the honeybee. The female offspring mature in about 10 days and mate within the trachea (Pettis and Wilson, 1989). Mated females leave the tracheae to seek a new host bee moving from bee to bee

\footnotetext{
* Corresponding author: jmcmullan@eircom.net

${ }^{1}$ Manuscript editor: Marla Spivak
} 
via the pleural hair (Hirschfelder and Sachs, 1952; Sammataro and Needham, 1996). The success rate of these foundress female mites entering the tracheae of new hosts was identified as the likely factor that made certain strains of honeybee susceptible or resistant to tracheal mite infestation (Danka and Villa, 1996). Danka and Villa (1998) further established that auto grooming was an important trait in bees with resistance, but considered that it was not the only factor involved. An attempt to show that the relative resistance of bee strains could be attributed to the cuticular chemistry of the bee host was not conclusive (Van Engelsdorf and Otis, 2001).

There has not been much recent research on the dynamics of intra-colony mite infestation. It has long been established that foundress female mites prefer young, newly emerged bees (Morgenthaler, 1930; Bailey, 1958; Lee, 1963; Giordani, 1977; Gary et al., 1989). It has been shown that air expelled from the prothoracic spiracles attracts the mites (Hirschfelder and Sachs, 1952). An in vitro demonstration has also shown that mites are influenced by particular cuticular hydrocarbons in the young bees (Phelan et al., 1991). What additional factors other than honeybee strain might affect variations in susceptibility to infestation? One potential factor is temperature stress during pupation. In other biological systems, stress has been shown to play an important role in susceptibility (Maurizio, 1934). There are certain indications that brood temperature may have a similar effect in the honeybee-mite interaction. First, deviations from normal brood temperature delay or speed up the rate of emergence of callow bees. The susceptibility of a honeybee to tracheal mite infestation is at its peak at emergence and reduces rapidly with age (Morgenthaler, 1930; Gary et al., 1989). This critical initial condition of the bee may be influenced by an abnormal rate of development. Second, mortality in tracheal mite infested colonies is highest in cold climates (Otis and Scott-Dupree, 1992) and this mortality typically occurs in the temperature-stressed late winter/early spring period. While healthy colonies of Apis mellifera have good regulation of brood temperature, it is also known that in adverse conditions the brood temperature held by the bees can be well below typical levels. Kronenberg and Heller (1982) established that in adverse conditions the bees maintained the capped brood and uncapped brood cell mean temperatures $( \pm$ s.d. $)$ at $31.3^{\circ} \mathrm{C}\left( \pm 1.9^{\circ} \mathrm{C}\right)$ and $27.5^{\circ} \mathrm{C}\left( \pm 4.1^{\circ} \mathrm{C}\right)$ respectively. Owens (1971) demonstrated that at an ambient temperature of $-14{ }^{\circ} \mathrm{C}$ the temperature within the brood area ranged from $29.5-34.5^{\circ} \mathrm{C}$. Conversely, in normal conditions bees that are not healthy would have difficulty regulating brood temperature through reduced bee numbers and restricted ability of wing muscles to generate heat. The rapid collapse of colonies that die with Acarapis woodi infestation may be partly explained by a relationship between reduced brood temperature and an increased susceptibility to infestation.

Here we test the hypothesis that callow bees from brood pupated at a low temperature are more susceptible to tracheal mite infestation than brood pupated at a more typical temperature.

\section{MATERIALS AND METHODS}

\subsection{Laboratory bioassay}

The experiment was undertaken in the March/ April period 2003 using bees from colonies in North County Dublin, Ireland. A laboratory bioassay was employed using inoculation cages of infested bees into which were introduced the newly-emerged worker bees to be tested. A similar approach had originally been used to measure migration and reproduction of mites (Gary and Page, 1987). Throughout we will refer to the infested bees as 'host' bees and the newly-emerged bees to be tested as 'target' bees (terminology adapted from Gary and Page). Previous experiments on honeybee susceptibility have shown a good correlation between the results from short-term bioassays and from field colonies (Page and Gary, 1990; Danka and Villa, 1996; Nasr et al., 2001).

Two inoculation cages were used. The cages were $16 \mathrm{~cm}$ in height and $6.5 \mathrm{~cm}$ in diameter (giving a total volume of $531 \mathrm{~cm}^{2}$ ) and were made from mesh screen wire of 3.1 mesh to the $\mathrm{cm}$. A piece of used brood comb (sterilized in $80 \%$ acetic acid fumes and ventilated) measuring $5 \mathrm{~cm} \times 4 \mathrm{~cm} \times 2 \mathrm{~cm}$ was suspended from the top of the cage.

\subsection{Host bees}

The infested host bees came from a colony where mite prevalence had been increased in the previous 
two weeks by removing half of its emerging brood frames, which had the effect of increasing the concentration of mites in the callow bees that emerge from the remaining frames. Bees from this colony were taken from the crown board (inner cover) and the landing board, shaken into a holding box and given a light misting of water. Each inoculation cage was filled in turn with an estimated 300 infested worker bees. The bees, measured by volume, were introduced into inoculation cage 1 using a funnel. A sample of sixty bees was taken from the holding box, placed in numbered boxes and stored at $-30{ }^{\circ} \mathrm{C}$. The bees were later dissected to give a measure of the host bee infestation in cage 1 . The procedure was repeated for inoculation cage 2 .

\subsection{Target bees}

The target bees were obtained from three medium/strong colonies (bees covering 7-10 frames of a 12 frame brood box) from three different apiaries in North County Dublin. One apiary was located in an urban coastal area, another in a mixed urban/ rural area one mile from the coast and the third in a rural area three miles from the coast. A frame of brood with the adhering bees brushed off was taken from each of the three colonies on 27th March 2003 and each inserted into a separate stainless steel frame cage. These cages were put into insulated nucleus boxes, transported to the laboratory and transferred to a dark incubator at $30{ }^{\circ} \mathrm{C}$ and a relative humidity of median (range) $55 \%( \pm 8 \%$ ), within half an hour of leaving the hive. For the following 9 days callow bees were removed morning and evening from each of the three cages. These bees were not included in the experiment. On 5th April (9 days later) a second frame of brood, adjacent in the hive to the frame already removed, was taken from each of the three target colonies and incubated at $34^{\circ} \mathrm{C}$. The brood temperature of the three target colonies had been monitored while the frames were in the hive to ensure that the brood was being pupated at normal hive temperature $\left(34^{\circ} \mathrm{C}\right)$ for the preceding 9 days. Temperature readings, median (range) of $34.4^{\circ} \mathrm{C}$ $\left( \pm 0.5^{\circ} \mathrm{C}\right), 34.6^{\circ} \mathrm{C}\left( \pm 0.7^{\circ} \mathrm{C}\right)$ and $34.6^{\circ} \mathrm{C}\left( \pm 0.5^{\circ} \mathrm{C}\right)$ for colonies 1,2 and 3 respectively were recorded during the period. From sample readings, the relative humidity in the hives was in the range 54\% $( \pm 10 \%)$. Consequently, because pupating bees are isolated from all other aspects of the hive environment, the only difference between the control and treatment bees was the temperature at which they were pupated, with the control bees pupating at $34^{\circ} \mathrm{C}$ for 9 days and the treatment bees pupating at $30^{\circ} \mathrm{C}$ for 9 days.

At eight-hour intervals over the next 24 hours callow bees emerging from the six frames were collected in separate polystyrene cups that had a smear of petroleum jelly along the top to prevent the callow bees from climbing out. Bees were chosen randomly from the polystyrene cups and (using surgical gloves to handle them) a 1-2 mm spot of Testor's ${ }^{\mathrm{TM}}$ gloss enamel paint was applied to the V-VI tergites on the abdomen of the callow bees; i.e. six different colours were used to mark these target bees. Previous work has shown that there is no effect on mite migration of marking in this way (Smith et al., 1991). Over a 24-hour period, thirty marked bees from each of the six frames were introduced by funnel into each of the two inoculation cages giving a total of 180 marked bees in each cage.

\subsection{Inoculation process}

The inoculation cages were maintained in a dark incubator at $32{ }^{\circ} \mathrm{C}$ and $50 \% \mathrm{RH}$. The bees were provided ad libitum with sugar syrup (50\%) and water via gravity feeding vials at the top of the cages. A supply of freshly gathered pollen was provided on the floor of each cage. This pollen was delivered through the vial-feed openings on top thus enabling access even when dead bees gathered on the floor. The experiment was concluded after 7 days, based on the evidence that the first adult mites to mature are the males after 8 days (Pettis and Wilson, 1989). Hence after 7 days the only adult mites present are the founding females. The dead bees were removed from the bottom of the cage, segregated and counted. The live bees were held on ice for 4-8 hours, and then taking each cage in turn were segregated into host and the six categories of target bees, and counted. A sample of sixty host bees was randomly chosen from each cage, placed in numbered boxes and stored at $-30{ }^{\circ} \mathrm{C}$. The target bees from each cage were also placed in numbered boxes and stored at $-30{ }^{\circ} \mathrm{C}$ to await dissection.

\subsection{Dissection technique}

The thoracic disk method is the most commonly used technique of dissecting bees for tracheal mite examination of large numbers of bees (Shimanuki and Knox, 2000). This method requires the use of 5$10 \%$ potassium hydroxide solution, and incubation of the disks for $16-24$ hours at $37^{\circ} \mathrm{C}$ to clear the bees' tissues. A preliminary test of this technique was conducted but was abandoned because of its inability to provide accurate estimates of mite intensity. Difficulty in distinguishing the different stages of mite development was also a major problem.

The bees were dissected using a modification to the classic technique of removing the head and thoracic collar as described by Lorenzen and Gary (1986). The prothoracic tracheae were removed and placed on a double-sided tape placed on a glass slide. Using a stereomicroscope at 60-100X magnification, each trachea was opened using a dissecting needle. 
Table I. Summary of mite infestation parameters (means \pm standard errors) for all target bees for brood treatment temperatures of $34^{\circ} \mathrm{C}$ and $30^{\circ} \mathrm{C}$.

\begin{tabular}{lcc}
\hline Mite Infestation & \multicolumn{2}{c}{ Brood Treatment Temperature } \\
Parameters (All bees) & $34{ }^{\circ} \mathrm{C}$ & $30^{\circ} \mathrm{C}$ \\
\hline Prevalence $(\%)^{1}$ & $20 \pm 3$ & $41 \pm 4$ \\
Abundance $^{2}$ & $0.95 \pm 0.18$ & $1.74 \pm 0.24$ \\
Intensity $^{3}$ & $4.65 \pm 0.51$ & $4.22 \pm 0.43$ \\
Mean fecundity $^{4}$ & $2.74 \pm 0.33$ & $2.73 \pm 0.25$ \\
\hline
\end{tabular}

The mite infestation terms used are defined as:

${ }^{1}$ Prevalence, number of infested bees in a sample (expressed here as a \%);

2 Abundance, total number of mites per bee in a sample;

${ }^{3}$ Intensity, total number of mites per infested bee in a sample;

${ }^{4}$ Mean fecundity, mite offspring per female mite over a given time period.

The number of adult mites, larvae and eggs were counted and recorded.

\subsection{Statistical analyses}

To test the effects of brood temperature, inoculation cage, colony and their interactions on the likelihood of a host bee becoming infested by tracheal mites we used a binary logistic regression. The forward log-likelihood procedure was applied. Brood temperature was coded as an indicator variable, while cage and colony were coded as deviation variables.

Mite abundance data were analyzed in a 3-way ANOVA, with brood temperature as a fixed factor, and cage and colony as random factors. While, even with transformation, the data did not meet the assumptions of normality and homogeneity of variances, for a large and balanced design, ANOVA are highly robust to such deviations (Underwood, 1997).

\subsection{Definitions}

The infestation terms used in this paper are defined below, following Bush et al. (1997).

Prevalence: number of infested bees in a sample (expressed here as a \%);

Abundance: total number of mites per bee in a sample;

Intensity: total number of mites per infested bee in a sample;

Mean fecundity: mite offspring per female mite over a given time period.

\section{RESULTS}

\subsection{Mite prevalence}

The brood temperature had a significant effect on mite prevalence (Logistic regression:
Wald statistic $=46.157$, d.f. $=1, P<0.001$ ) There was a two-fold increase in the overall prevalence from $20 \%$ at $34{ }^{\circ} \mathrm{C}$ to $41 \%$ at $30{ }^{\circ} \mathrm{C}$. (Tab. I and Fig. 1). There were no significant effects of cage or colony.

\subsection{Mite abundance, intensity and fecundity}

There was no effect of brood temperature $(\mathrm{F}[1,2.54]=6.021, P=0.107)$, colony $(\mathrm{F}[2,2.13]=$ $0.76, P=0.563)$, cage $(\mathrm{F}[1,1.12]=0.225, P=$ 0.711 ) or their interactions on mite abundance. Despite this, the overall mite abundance increased by $82 \%$, from 0.95 at $34^{\circ} \mathrm{C}$ to 1.74 mites/bee at $30{ }^{\circ} \mathrm{C}$ (Tab. I). The lack of a temperature effect in the ANOVA (see above) was probably due to the large number of uninfested bees (229 uninfested / 331 total) rather than the absence of a real effect. The power of this test to detect a temperature effect was only 0.354 .

The corresponding mite intensities for treatment at $34{ }^{\circ} \mathrm{C}$ and $30^{\circ} \mathrm{C}$ were 4.65 and 4.22 mites per infested bee respectively (t-test: $P=0.551)$, while the mean fecundity of 2.74 $\left(34^{\circ} \mathrm{C}\right)$ and $2.73\left(30^{\circ} \mathrm{C}\right)$ mites was similar (ttest: $P=0.976)$. In 17 instances, offspring were found in the tracheae of the target bees but with no associated foundress female present. As in the case of Gary et al. (1989) we assumed that the foundress females had migrated further into the trachea and were not detected during the dissection. Accordingly, if in these cases one female mite were assigned 


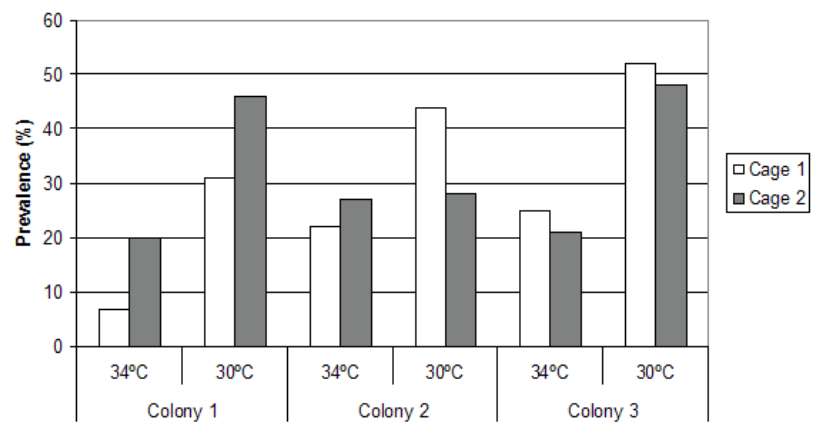

Figure 1. Mite prevalence levels (percentage values) for the target bees from the three colonies, after a period of seven days in the two inoculation cages. The figure illustrates the effect of brood treatment temperature on the mite prevalence.

Table II. Fecundity analysis for all target bees for the two brood temperature treatments of $34^{\circ} \mathrm{C}$ and $30{ }^{\circ} \mathrm{C}$.

\begin{tabular}{|c|c|c|c|c|c|c|c|}
\hline \multirow{2}{*}{$\begin{array}{l}\text { Treatment } \\
\text { Temp. }{ }^{\circ} \mathrm{C}\end{array}$} & \multicolumn{2}{|c|}{ Female Mites } & \multicolumn{3}{|c|}{ Offspring $^{2}$} & \multirow{2}{*}{$\begin{array}{l}\text { Adjusted } \\
\text { Mean } \\
\text { Fecundity }{ }^{3}\end{array}$} & \multirow{2}{*}{$\begin{array}{l}\text { Overall Ratio } \\
\text { Larvae / Eggs }\end{array}$} \\
\hline & Actual & Adjusted $^{1}$ & Larvae & Eggs & Total & & \\
\hline 34 & 39 & 43 & 34 & 85 & 119 & $2.77 \pm 0.32$ & 0.40 \\
\hline 30 & 67 & 80 & 60 & 160 & 220 & $2.75 \pm 0.22$ & 0.38 \\
\hline
\end{tabular}

${ }_{1}$ Actual mites present plus an allocation of one female mite for each occasion that offspring was present with no female mite;

2 Eggs and larvae;

3 Adjusted mean fecundity (mean \pm SE).

to the offspring, an adjusted mean fecundity would be obtained encompassing all of the mite population (Tab. II).

The overall ratio of larvae to eggs was also similar for the two treatments at 0.40 for $34^{\circ} \mathrm{C}$ and 0.38 for $30^{\circ} \mathrm{C}$ (Tab. II). This indicated that the temporal distribution of the foundress mites entering the tracheae was similar (assuming that the time for eggs to hatch was the same). Therefore, since the mean fecundity (and adjusted mean fecundity) and the temporal distribution of entry of foundress mites were similar for both treatments, it indicated that the egg-laying rate (fecundity) of the mites was also similar.

\subsection{Inoculation pressure (Cages 1 and 2)}

It was planned to have a minimum of 300 infested host bees in each inoculation cage.
However, using a volumetric measurement to estimate the number of water-misted bees resulted in excess numbers of $20 \%$ in cage 1 and over $40 \%$ in cage 2 (Tab. III). The number of infested host bees and the total mites present at all stages were significantly lower in inoculation cage 2 , even after allowing for the larger number of host bees initially. The resulting inoculation pressure was about four fifths that of cage 1 yet the number of adult females that migrated to the target bees and the total number of mites at all stages in target bees in cage 2 was similar to that in cage $1 ; 53$ vs. 53 and 218 vs. 227 respectively.

\subsection{Recovery and mortality rates (Target and host bees)}

There was a high recovery rate for the target bees in both cages, and mortality rates were 
Table III. Survival, recovery and feeding rates for host and target bees

\begin{tabular}{lccccccc}
\hline Bee & \multicolumn{3}{c}{ Cage 1 } & & \multicolumn{3}{c}{ Cage 2 } \\
\cline { 2 - 3 } \cline { 7 - 8 } Colony & Alive (\%) & Dead (\%) & Total & & Alive (\%) & Dead (\%) & Total \\
\hline Host: & $304(83 \%)$ & $63(17 \%)$ & 367 & & $296(68 \%)$ & $142(32 \%)$ & 438 \\
Target: & & & & & & \\
Brood at 34 ${ }^{\circ} \mathrm{C}$ & $28(97 \%)$ & $1(3 \%)$ & 29 & & $25(83 \%)$ & $5(17 \%)$ & 30 \\
Colony 1 & $27(96 \%)$ & $1(4 \%)$ & 28 & & $30(100 \%)$ & $0(0 \%)$ & 30 \\
Colony 2 & $28(90 \%)$ & $3(10 \%)$ & $* 31$ & & $28(97 \%)$ & $1(3 \%)$ & 29 \\
Colony 3 & & & & & & \\
Brood at 30 ${ }^{\circ} \mathrm{C}$ & $29(97 \%)$ & $1(3 \%)$ & 30 & & $26(90 \%)$ & $3(10 \%)$ & 29 \\
Colony 1 & $27(96 \%)$ & $1(4 \%)$ & 28 & & $29(97 \%)$ & $1(3 \%)$ & 30 \\
Colony 2 & $25(83 \%)$ & $5(17 \%)$ & 30 & & $29(97 \%)$ & $1(3 \%)$ & 30 \\
Colony 3 & $164(93 \%)$ & $12(7 \%)$ & 176 & & $167(94 \%)$ & $11(6 \%)$ & 178 \\
Total (Target) & & & & & & \\
All Bees: & & 33.3 & & & & 29.1 & \\
Food / bee / day $(\mu \mathrm{L})$ & & & & & & & \\
\hline
\end{tabular}

* 30 target bees introduced into each cage except cage 1 , colony $3\left(34^{\circ} \mathrm{C}\right)$ where 31 bees were introduced in error.

similar at $7 \%$ for cage 1 and $6 \%$ for cage 2 (Tab. III). This was in contrast to the mortality rate for the older host bees that differed widely at $17 \%$ for cage 1 and $32 \%$ for cage 2 . The food consumption per bee in cage 2 was also much lower during the inoculation period (29.1 $\mu \mathrm{L}$ vs. $33.3 \mu \mathrm{L}$; Tab. III). The above observations plus the fact that there were initially $20 \%$ more host bees in cage 2 and the presence of dysentery on the sixth day would indicate that these bees were in a more 'stressed' state.

\subsection{Brood delay time}

The reduction in brood temperature resulted in a considerable lengthening of the time period from sealing of the brood cells to emergence of the callow bees. The callow bees used in the experiment had been pupated at $30{ }^{\circ} \mathrm{C}$ for a period of 9 days. However, pupation of the three brood combs continued until all of the bees had emerged. The callow bees emerged from the brood raised at $30^{\circ} \mathrm{C}$ within an average time of 18.1 days (ranging from 17.6 to 18.3 days for the three target colonies). This represented a delay of 5.1 days from the typical emergence time in normal conditions of 13 days. All the bees appeared in a healthy condition. The proportion of bees that did not emerge (dead in the cell) was similar for the bees raised at $30{ }^{\circ} \mathrm{C}(\mathrm{n}=5366)$ and $34^{\circ} \mathrm{C}(\mathrm{n}=$ 6492 ) at $1.0 \%$ and $1.1 \%$ respectively. The target bee mortality in the inoculation cages was similar for both treatments at $12 / 177\left(30^{\circ} \mathrm{C}\right)$ and $11 / 177\left(34^{\circ} \mathrm{C}\right)$. Hence the treatment had a delaying effect but had no mortality effect.

\section{DISCUSSION}

Reducing brood temperature increased the susceptibility of honeybees to tracheal mite infestation by a factor of two. We believe that this is the first experimental demonstration of variation in intra-colonial resistance to tracheal mites. Furthermore, the analysis of mite abundance showed that this variation relates only to the initial establishment of mites, as mother mites produced the same number of offspring regardless of whether their host had pupated at $30^{\circ} \mathrm{C}$ or $34^{\circ} \mathrm{C}$.

The above could help to explain aspects of the epidemiology of tracheal mite infestation in honeybees. There is a significant increase in mortality in winter where $>30 \%$ of bees in a hive are infested (Bailey, 1961). Typically, colonies that collapse with the 'Isle of Wight disease' show no signs of viral paralysis 
(Adam, 1968). This has been the recent experience of mortality in tracheal mite infested colonies in Ireland (J.McM. personal observation). Other studies have shown that winter mortality rates in colonies with tracheal mites are generally higher in cold climates (Eischen, 1987; Otis and Scott-Dupree, 1992). Honeybees in a colony with a moderate infestation will have reduced capability to use their flight muscles to generate thoracic heat due to mites and associated debris blocking the prothoracic tracheae (Komeili and Ambrose, 1991). The combined effects of the reduced ability to generate thoracic heat and the increased susceptibility to mite infestation of a colony under low temperature conditions (per our findings) are likely to be critical factors mitigating against colony survival in winter. Brood areas in winter/ early spring have been negatively correlated with mite infestation (Otis and Scott-Dupree, 1992). A colony during this critical period requires an influx of young healthy bees if it is to survive. Our results show that reduced brood temperature will increase the vulnerability of callow bees to tracheal mite infestation and the development of the brood nest will be restricted limiting the ability of the colony to adequately replace the old winter bees. Reduced bee numbers will then contribute to lower brood temperature, increased susceptibility and the colony viability will spiral downwards.

Variability in host bee mortality between cages indicates that the bees in inoculation cage 2 were more stressed than those in cage 1 . It is also noteworthy that while the inoculation pressure in cage 2 was $20 \%$ less, the overall infestation levels in the target bees in the two cages were similar. It would appear that this cage-specific stress increased either migration of mites from host bees or the overall susceptibility of the target bees to tracheal mite infestation.

Overall the results from our experiment concur with the conclusions of Danka and Villa (1996) that differential susceptibility is governed by the success rate of migrating foundress mites entering the tracheae and that mite fecundity does not play a major role. Gary et al. (1989) established that bees were most susceptible up to four days old, confirming the findings of Morgenthaler (1930, 1931). In both cases the plot of bee susceptibility vs. bee age ('susceptibility curve') showed the susceptibility to the tracheal mites falling off rapidly from the level at emergence to almost zero at a bee age of five days. The much higher susceptibility of the bees pupated at $30^{\circ} \mathrm{C}$ in our experiment would indicate a 'susceptibility curve' above that for the higher brood temperature with, for example, a much higher susceptibility at emergence or a slower decline with age of bee. The former is suggested, as an analysis of the data on larvae / eggs ratios from our experiment indicated that the temporal distribution of the mites entering the tracheae was similar for both treatments.

The reason why a lower brood temperature results in an increased susceptibility of honeybees to tracheal mite infestation has not been established in this experiment. Further work is required to isolate the mechanism involved.

\section{ACKNOWLEDGEMENTS}

The authors would like to thank the members of Fingal North Dublin Beekeepers' Association and John \& Dorothy Stapleton for access to honeybee colonies, and Martyn Linnie, Peter Stafford and Alison Boyce for help in the laboratory. Many thanks also to Gard Otis, University of Guelph and Lilia de Guzman, USDA/ARS, Baton Rouge who provided timely advice on experiment procedures. Helpful comments from three anonymous reviewers and Celia Holland improved the clarity of the manuscript.

Résumé - La température de nymphose du couvain agit sur la susceptibilité des abeilles domestiques (Apis mellifera) à être infestées par l'acarien Acarapis woodi. Il y a 100 ans survenait dans le sud de l'Angleterre la première manifestation d'une épidémie sans agent pathogène connu parmi les abeilles domestiques. L'acarien des trachées, Acarapis woodi (Rennie), découvert en 1919, fut associé à l'épidémie qui devint connue sous le nom de « maladie de l'île de Wight ». Depuis de grosses pertes ont été causées aux ruches dans le monde entier. L'acarien se tient principalement dans les trachées prothoraciques et se nourrit de l'hémolymphe des abeilles. Il existe une controverse au sujet du pouvoir pathogène de l'acarien. La majeure partie de la recherche réalisée à ce jour s'est concentrée sur la sensibilité des diverses souches d'abeilles à l'acarien. Cet article, par contre, considère l'action de la température du couvain sur la sensibilité d'une souche d'abeilles à l'infestation. Une expérience utilisant un test biologique en laboratoire a été entreprise pour comparer la sensibilité des abeilles naissantes issues d'un couvain élevé à basse température $\left(30^{\circ} \mathrm{C}\right)$ avec celle d'abeilles issues d'un couvain élevé à température 
normale $\left(34{ }^{\circ} \mathrm{C}\right)$. La réduction de la température a provoqué un retard de $5 \mathrm{j}$ dans l'émergence des abeilles. Les résultats montrent que les abeilles élevées à basse température étaient deux fois plus infestées. Le taux de reproduction des acariens dans les trachées était le même dans les deux cas. Ces résultats peuvent aider à expliquer un caractère de l'épidémiologie des colonies faiblement infestées, à savoir le déclin et la mortalité à la fin de l'hiver et au début du printemps. Le mécanisme responsable de cette sensibilité accrue des abeilles élevées à basse température reste inconnu.

\section{Apis mellifera / Acarapis woodi / infestation / sen- sibilité / température du couvain}

\section{Zusammenfassung - Bruttemperatur beeinflusst} die Anfälligkeit der Honigbienen (Apis mellifera) für den Befall durch Tracheenmilben (Acarapis woodi). Vor 100 Jahren brach bei Honigbienen zum ersten Mal eine Epidemie mit unbekannten Pathogenen in Südengland aus. Sie wurde als 'Isle of Wight Krankheit' bezeichnet. In diesem Zusammenhang wurde die Tracheenmilbe Acarapis woodi (Rennie) im Jahr 1919 entdeckt. Inzwischen kamen in der ganzen Welt flächendeckende Verluste bei Apis mellifera (L.) Völkern durch die Tracheenmilbe vor. Die Milben halten sich vor allem in den Tracheen des Prothorax (Bruststücks) auf und ernähren sich von der Hämolymphe der Bienen. Allerdings wird die Pathogenität der Milbe kontrovers beurteilt. Bis heute hat sich die Forschung auf die Anfälligkeit von verschiedenen Linien der Honigbienen gegen die Milben konzentriert. Dagegen beschäftigt sich diese Arbeit mit dem Einfluss der Temperatur bei der Brutaufzucht auf die Anfälligkeit innerhalb einer Linie der Honigbienen. Im Versuch mit einem Biotest im Labor wurde die Empfindlichkeit von frisch geschlüpften Bienen verglichen, die entweder bei niedrigen Temperaturen $\left(30^{\circ} \mathrm{C}\right)$ oder bei normalen Temperaturen $\left(34^{\circ} \mathrm{C}\right)$ aufgezogen wurden. Die niedrige Temperatur verursachte eine Verzögerung des Schlupfes der Bienen aus den Brutzellen von mehr als 5 Tagen. Die Ergebnisse zeigten, dass Bienen, aufgezogen bei niedrigen Temperaturen, doppelt so häufig mit Milben befallen waren. Die Vermehrungsrate der Milben in den Tracheen hatte in beiden Fällen einen ähnlichen Wert. Diese Ergebnisse könnten dazu beitragen, die Grundzüge der Epidemiologie von mit Milben nur gering befallenen Völkern zu erklären, besonders ihre Schrumpfung und Sterblichkeit in der Zeit des späten Winters und des frühen Frühjahrs. Der Mechanismus für die erhöhte Empfindlichkeit der bei niedrigen Temperaturen aufgezogenen Bienen bleibt unbekannt.

\section{Apis mellifera / Acarapis woodi / Tracheenmilbe / Bruttemperatur}

\section{REFERENCES}

Adam Brother (1968) "Isle of Wight" or acarine disease: Its historical and practical aspects, Bee World 49, 6-18.

Bailey L. (1958) The epidemiology of the infestation of honeybee, Apis mellifera L., by the mite Acarapis woodi Rennie and the mortality of bees, Parasitology 48, 493-506.

Bailey L. (1961) The natural incidence of Acarapis woodi (Rennie) and the winter mortality of honeybee colonies, Bee World 42, 96-100.

Bailey L., Ball B.V. (1991) Honey Bee Pathology, Academic Press London, pp. 78-96.

Bush J.O., Lafferty K.D., Lotz J.M., Scoldak A.W. (1997) Parasitology meets ecology on its own terms; Margolis et al. revisited, J. Parasitol. 83, $575-583$.

Collison C.H. (2001) The pathological effects of the tracheal mite on its host, in: Webster T.C., Delaplane K.S. (Ed.), Mites of the honeybee, Dadant and Sons, Hamilton, Illinois, pp. 57-71.

Danka R.G. (1991) Resistance of honey bees to tracheal mites, in: Webster T.C., Delaplane K.S. (Eds.), Mites of the honeybee, Dadant and Sons, Hamilton, Illinois, pp. 117-129.

Danka R.G., Villa J.D. (1996) Influence of resistant honey bee hosts on the life history of the parasite Acarapis woodi, Exp. Appl. Acarol. 20, 313-322.

Danka R.G., Villa J.D. (1998) Evidence of autogrooming as a mechanism of honeybee resistance to tracheal mite infestation, J. Apic. Res. 37, 39-46.

Eischen F.A. (1987) Overwintering performance of honey bee colonies heavily infested with Acarapis woodi (Rennie), Apidologie 18, 293-304.

Gary N.E., Page R.E. (1987) Phenotypic variation in susceptibility of honey bees, Apis mellifera, to infestation to tracheal mites, Acarapis woodi, Exp. Appl. Acarol. 3, 291-305.

Gary N.E., Page R.E., Lorenzen K. (1989) Effect of age of worker honeybees (Apis mellifera) on tracheal mites (Acarapis woodi) infestation, Exp. Appl. Acarol. 7, 153-160.

Giordini G. (1977) Facts about acarine mites, in: Proc. Int. Congr. Apic. XXVI, Adelaide, Australia, pp. 459-467.

Hirschfelder H., Sachs H. (1952) Recent research on acarine disease, Bee World 33, 201-209.

Komeili A.B., Ambrose J.T. (1991) Electron microscope studies of the tracheae and flight muscles of non infested, Acarapis woodi infested and crawling honey bees Apis mellifera), Am. Bee J. 131, 253-257.

Kronenberg F., Heller H.C. (1982) Colonial thermoregulation in honey bees (Apis mellifera), $\mathrm{J}$. Comp. Physiol. 148, 65-76.

Lee C. (1963) The susceptibility of honey bees of different ages to infestation by Acarapis woodi (Rennie), J. Insect. Pathol. 5, 11-15. 
Lorenzen K., Gary N.E. (1986) Modified dissection technique for dissection of tracheal mites (Acari: Tarsonemidae) in honey bees (Hymenoptera: Apidea), J. Econ. Entomol. 79, 1401-1403.

Morgenthaler O. (1930) New investigations on acarine disease, Bee World 11, 49-50.

Morgenthaler O. (1931) An acarine disease experimental apiary in the Bernese Lake-District and some results obtained there, Bee World 12, 8-10.

Maurizio A. (1934) Über die Kalkbrut (PericystisMykose) der Bienen, Arch. Bienenkd. 15, 165193.

Nasr M.E., Otis G.W., Scott-Dupree C.D. (2001) Resistance to Acarapis woodi by honey bees (Hymenoptera: Apidae): Divergent selection and evaluation of selection process, J. Econ. Entomol. 94, 332-338.

Otis G.W., Scott-Dupree C.D. (1992) Effects of Acarapis woodi on overwintered colonies of honey bees (Hymenoptera: Apidea) in New York, J. Econ. Entomol. 85, 40-46.

Owens C.D. (1971) The Thermology of wintering honey bee colonies, Tech. Bull. U.S. Dept. Agric. 1429, 1-32.

Page R.E., Gary N.E. (1990) Genotypic variation in susceptibility of honeybees (Apis mellifera) to infestation by tracheal mites (Acarapis woodi), Exp. Appl. Acarol. 8, 275-283.
Pettis J.S., Wilson W.T. (1989) Reproduction of Acarapis woodi as related to seasonal host longevity, Am. Bee J. 129, 820.

Phelan L.P., Smith A.W., Needham G.R. (1991) Mediation of host selection by cuticular hydrocarbons in the honeybee tracheal mite Acarapis woodi (Rennie), J. Chem. Ecol. 17, 463-473.

Rennie J. (1921) Isle of Wight disease in hive bees acarine disease: the organism associated with the disease-Tarsonemus woodi, Trans. R. Soc. Edinburgh 52, 768-779.

Sammataro D., Needham G.R. (1996) Host-seeking behaviour of tracheal mites (Acari: Tarsonemidae) on honey bees (Hymenoptera: Apidae), Exp. Appl. Acarol. 20, 121-136.

Shimanuki H., Knox D.A. (2000) Diagnosis of honey bee diseases, U.S. Dept. Agric. Ag. Handb. No. 690.

Smith A.W., Needham G.R., Page R.E. Jr., Fondrik M.K. (1991) Dispersal of the honeybee tracheal mite, Acarapis woodi (Acari: Tarsonemidae) to old bees, Bee Sci. 1, 95-99.

Underwood A.J. (1997) Experiments in Ecology, Cambridge University Press, pp. 192-194.

Van Engelsdorf D., Otis G.W. (2001) The role of cuticular compounds in the resistance of honey bees (Apis mellifera) to tracheal mites (Acarapis woodi), Exp. Appl. Acarol. 25, 593-603. 